\title{
Leek Cultivation Guide for Florida ${ }^{1}$
}

\author{
Mary Dixon and Guodong Liu²
}

\section{General Description}

Leek (Allium porrum L.) is a member of Amaryllidaceae, a family with ornamental crops, like amaryllis, and with vegetable crops, like onion. Members of this family typically grow umbels composed of showy and radially symmetric flowers with six distinct to connate tepals. The parallel-veined, simple, entire leaves are flat and arranged basally. The black or blue seeds usually contain the pigment phytomelan (Castner 2004) (Figure 1). There are two types of leek typically grown: common leek and Chinese leek. Common leek can reach three feet tall and has a width of two inches (MacKenzie 2018). Chinese leek is thinner, shorter, and has stronger flavors (Figures 2 and 3). Both leeks are monocots that do not produce bulbs and are grown for fresh-market production. The edible portion is the cylinder of bundled leaf sheaths, commonly called a stem, stalk, or pseudostem (Danto 2013; Swamy and Gowda 2006).

Leek is a highly demanded vegetable because of its flavor and nutrient content. Leek cultivars commonly grown in Florida include 'Jolant', 'King Richard', 'Lancelot', 'Chives', 'Staro,' 'Megathon', 'Tivi', 'Tornado', and 'Verina' (Dittmar et al. 2019). Although there is great potential for leek to commercially grow in Florida due to demand and appropriate climatic conditions, the United States does not currently produce a significant quantity of leek compared to countries such as Indonesia, Turkey, and China (FAOSTAT 2019).

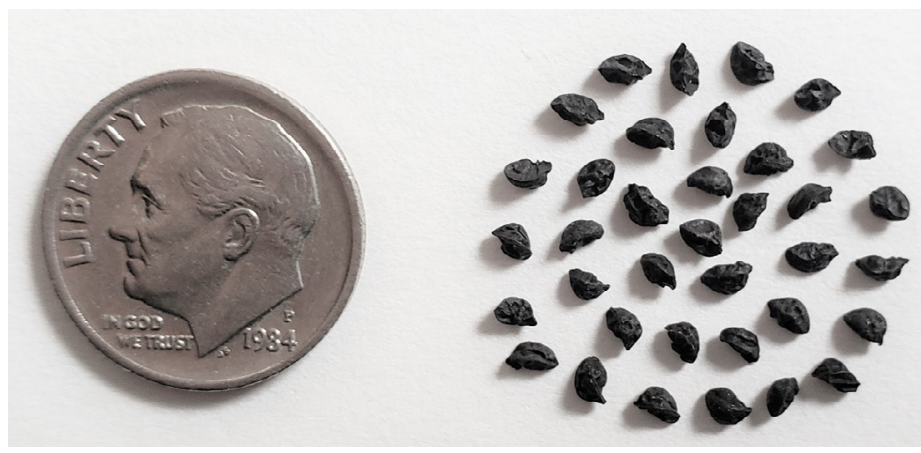

Figure 1. Dark leek seeds with a dime for scale. Credits: Mary Dixon, UF/IFAS

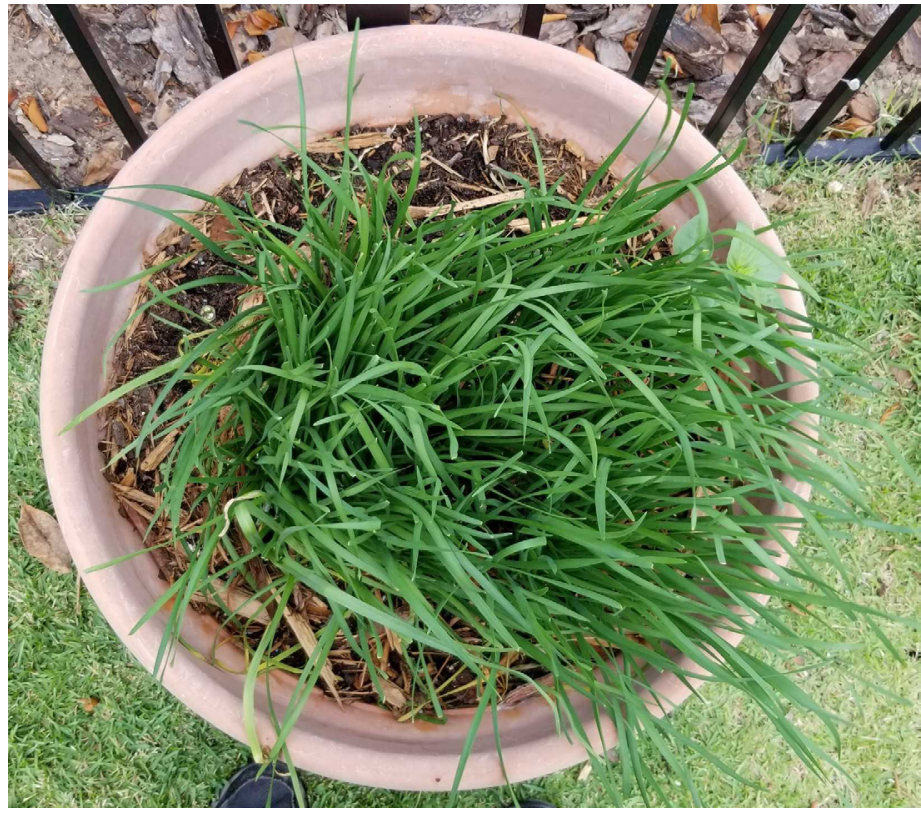

Figure 2. Chinese leek plants grown in a pot in a garden in Gainesville. Credits: Guodong Liu, UF/IFAS

1. This document is HS1388, one of a series of the Horticultural Sciences Department, UF/IFAS Extension. Original publication date October 2020. Visit the EDIS website at https://edis.ifas.ufl.edu for the currently supported version of this publication.

2. Mary Dixon, graduate student, and Guodong Liu, associate professor, Horticultural Sciences Department; UF/IFAS Extension, Gainesville, FL 32611.

The Institute of Food and Agricultural Sciences (IFAS) is an Equal Opportunity Institution authorized to provide research, educational information and other services only to individuals and institutions that function with non-discrimination with respect to race, creed, color, religion, age, disability, sex, sexual orientation, marital status,

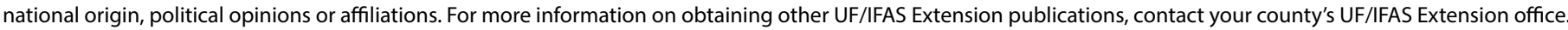
U.S. Department of Agriculture, UF/IFAS Extension Service, University of Florida, IFAS, Florida A \& M University Cooperative Extension Program, and Boards of County Commissioners Cooperating. Nick T. Place, dean for UF/IFAS Extension. 


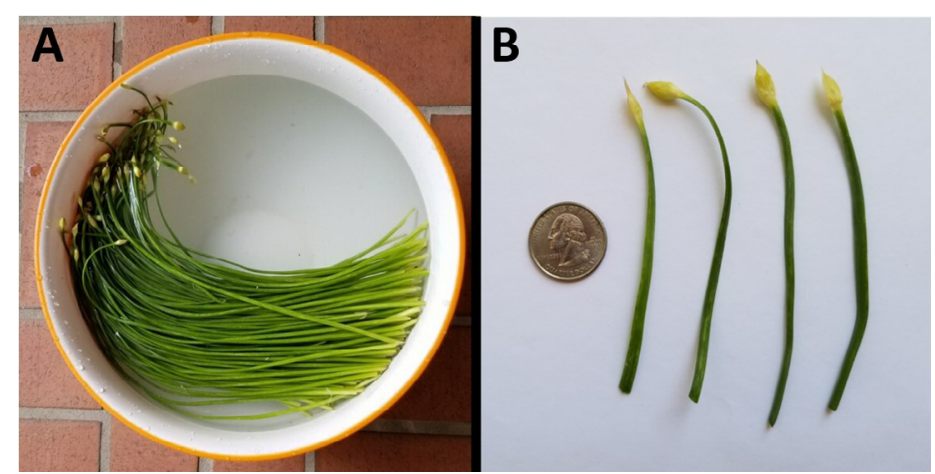

Figure 3. Chinese leek (A) and a quarter for scale (B). Credits: Guodong Liu, UF/IFAS

Leek is a cold-hardy, cool-season crop (Maynard and Hochmuth 2007). There are four categories of leek, each based on the season of maturity: summer, autumn, autumn and winter, and winter leeks (Swamy and Gowda 2006). The autumn, autumn and winter, and winter leeks are sometimes categorized together as winter leeks. The smaller and more vigorous summer leeks have light green leaves and are intended for harvest in the season planted (Danto 2013; Traunfeld 2010). The thicker and stronger-tasting winter leeks have blue-green keeled leaves and are intended for harvest in the following spring. Winter leeks can tolerate temperatures of $23^{\circ} \mathrm{F}\left(-5^{\circ} \mathrm{C}\right)$ (Danto 2013; Stephens 2015; Swamy and Gowda 2006; Traunfeld 2010). In general, leek grows optimally in temperatures of $55^{\circ} \mathrm{F}-75^{\circ} \mathrm{F}\left(12.8^{\circ} \mathrm{C}-\right.$ 23.9 $9^{\circ}$ ) (Maynard and Hochmuth 2007).

\section{Propagation}

Seed priming (controlled hydration of seeds inducing pregermination metabolic events) improves germination in wider ranges of environmental conditions, the percentage and rate of germination, and seedling growth and uniformity (McDonald 2000). Optimal temperatures for germination are between $64^{\circ} \mathrm{F}-72^{\circ} \mathrm{F}$ (Swamy and Gowda 2006). Direct seeding should take place from mid-September to mid-November in north Florida or in October in central to south Florida. Plant seeds at a depth of $1 / 4$ to $1 / 2$ inch and a rate of 3-4 lb/acre to achieve a plant population of 149,343 per acre. Distance should be 14-18 in. between rows and 3-4 in. between plants (Dittmar et al. 2019).

While leek can be grown from seeds or from transplants, transplanting is more common because leek takes 100-130 days to reach maturity (Dittmar et al. 2019). Leek transplants are usually ready once the seedlings reach 6 in. (Swamy and Gowda 2006) (Figure 4). Planting dates for transplants should be from November to January in north Florida or from December to January in central to south Florida. Space plants 4-6 in. apart and rows 14-18 in. apart to reach a plant population of 112,123 per acre (Dittmar et al. 2019). While seedlings are young, soil should be pulled around the base of the plant. This soil cover blanches the stem, making it white and tender (Danto 2013; Traunfeld 2010). Deep planting or ploughing may be necessary to develop the long white shafts (Swamy and Gowda 2006).

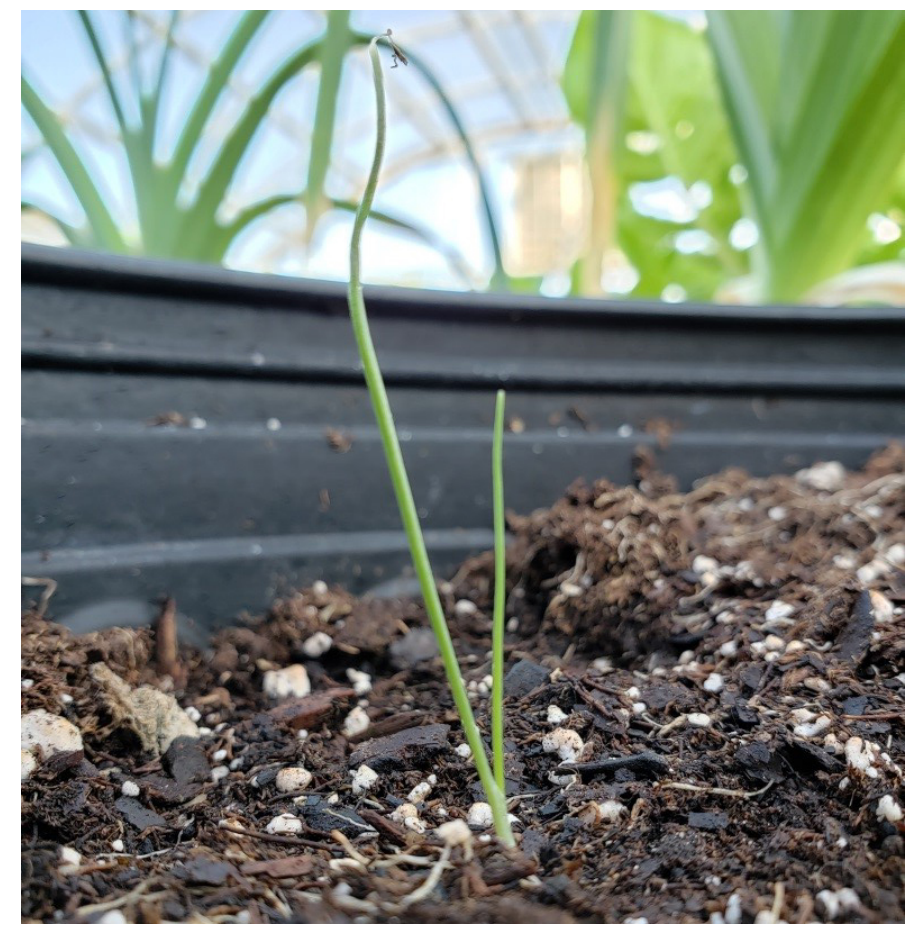

Figure 4. Young leek seedling nearly ready for transplant. Credits: Mary Dixon, UF/IFAS

\section{Growing Conditions}

Leek grows optimally with 8 hours of sunlight in loose, sandy soil with a pH of 6.5-7.0 (MacKenzie 2018; Swamy and Gowda 2006). Leek may be well suited for production in pots. The closely related Chinese leek (Allium tuberosum L.) has been successfully cultivated in one-gallon pots filled with a 2:1 mix of turf and perlite (Alan et al. 2019). These researchers produced an average of $9 \mathrm{oz}$ of aerial growth per pot and found that Chinese leek has potential for perennial cultivation for ornamental use in parks or gardens, and for annual cultivation for use as a potted herb. There is not a specific UF/IFAS recommendation for Chinese leek. However, Chinese leek, common leek, and bunching onion belong to the same genus, Allium, in the same amaryllis family, Amaryllidaceae. Therefore, the following fertilizer recommendation for common leek and bunching onion can be used for Chinese leek for the time being (Liu et al. 2019): $120 \mathrm{lb} / \mathrm{A}$ for nitrogen (N), 100-120 lb/A for low phosphorus (P), and 100-120 lb/A for low potassium (K). For medium and high phosphorus or potassium soils, no phosphorus or potassium is needed.

It is recommended to incorporate organic matter into the soil (Traunfeld et al. 2010) and inoculate with arbuscular 
mycorrhizal (AM) fungi (Glomus geosporum) (Nasir et al. 2018). Symbiosis with AM fungi is both common and beneficial, with advantages including increases in the availability of soil $\mathrm{P}$, greater acquisition of other poorly mobile nutrients, and better resistance to soilborne pathogens (Vosatka and Albrechtova 2009). Inoculation with the AM fungi increased polyphenol content of leek by $28 \%-1123 \%$ compared to the untreated control (Nasir et al. 2018). Increased polyphenol content benefits the nutritional quality of leek and its resistance to pests.

Water management for leek is critical; its shallow root system of 18-24 in. makes leek susceptible to water deficit, but excess water may result in fungal diseases (MacKenzie 2018; Maynard and Hochmuth 2007; Traunfeld et al. 2010). An irrigation treatment of $75 \%$ field capacity has been recommended for water-scarce regions (Kiremit and Arslan 2018). Leek is moderately saline tolerant and can grow using saline irrigation without yield loss if in systems with appropriate leaching and drainage controls. There is an approximate $10 \%$ loss in yield (relative stem fresh weight) for each unit increase in salinity above a threshold of 774 ppm (parts per million) (Kiremit and Arslan 2016).

Intercropping benefits growers by increasing gross incomes (33\% on average) while using less land ( $23 \%$ on average) (Martin-Guay et al. 2018). Intercropping can also have agronomic and yield benefits; systems with intercropped leek and dyer's wood (Isatis tinctoria L.) increased rooted zone from $1.6 \mathrm{ft}$ to $6.6 \mathrm{ft}$ and decreased inorganic soil nitrogen $(\mathrm{N})$ content by $46.4 \mathrm{lb} / \mathrm{acre}$ compared to control without dyer's wood (Xie and Kristensen 2017). Leek may be harvested as early as 60 days after planting, but more commonly it requires close to 120 days to fully mature (Figure 5). Once the stem reaches one inch in diameter, leek is usually ready for harvest. Harvest leek with turgid shoots and without withered leaf tips (Traunfeld et al. 2010).

\section{Weeds, Pests, and Diseases}

Weed control is an important step during the first two months of growth because leek grows slowly and poorly compared with weeds during this time. Mulching or intercropping may reduce weed pressure (Traunfeld et al. 2010; Baumann et al. 2000). Intercropping leek with celery in a row-by-row replacement design has shown to reduce the critical weed management period (Baumann et al. 2000).

Thrips (order Thysanoptera) are a major pest of leek. Many thrips require as few as 10 days to develop from egg to adult, but some may spend most of a year in pupal diapause. Larvae are typically bright red or yellow, and adults are dark (Daly et al. 1998). Thrips recede to the inner leaf blade, where they feed on the nutritious fluids in cells. Intercropping leek with subterranean clover (Trifolium subterraneum L.) has reduced thrips infestation (Theunissen and Schelling 1996).

Leek is host to numerous diseases, such as rust and fusarium wilt. Intercropping by undersowing with subterranean clover reduced the incidence of rust (Puccinia alii) (Theunissen and Schelling 1996). Leek is also susceptible to pink root rot, but dipping transplant roots in a $2 \%$ solution of fresh garlic (Allium sativum) extract has been shown to be effective in treating this disease (Biesiada et al. 2004). Soil fumigation may be implemented to control for fusarium wilt but may not be necessary, because reported incidence of this disease is low (Armengol et al. 2007). This trend may be due to sulfur compounds exuded from the roots. Intercropping with Chinese leek can reduce incidence of fusarium wilt because of its volatile root exudates (active biochemicals including dimethyl trisulfide, dimethyl disulfide, 2-propenyl methyl disulfide, 2-propenyl methyl trisulfide, and 2-methoxy-4-vinylphenol) that inhibit development of Fusarium oxysporum f. sp. cubense tropical race 4 (Zuo et al. 2015).

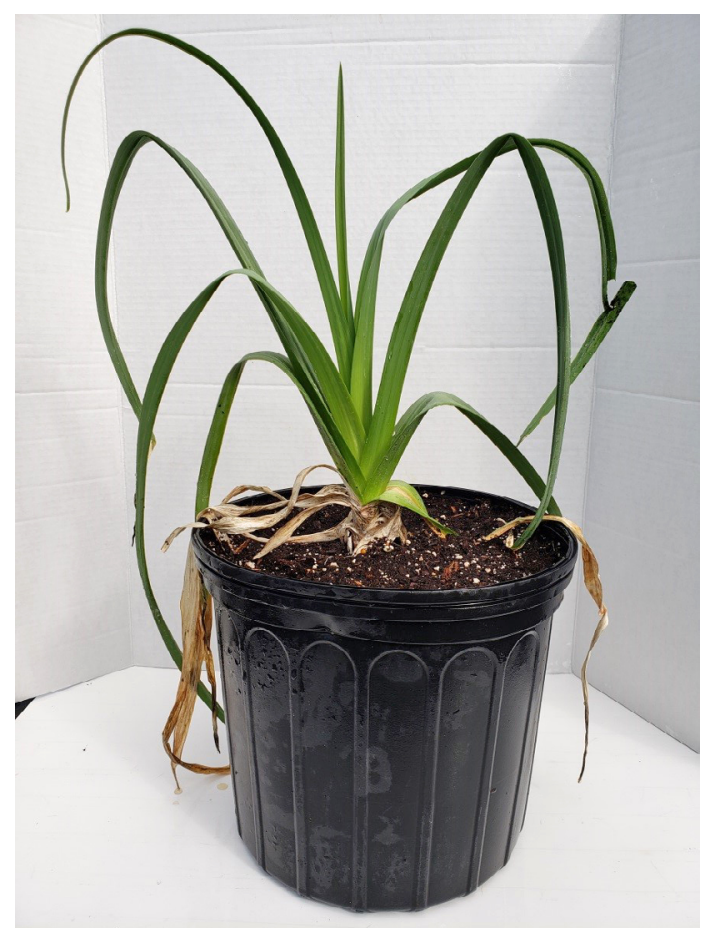

Figure 5. Mature common leek after 90 days of growth. Credits: Mary Dixon, UF/IFAS 


\section{Agricultural, Culinary, and Medicinal Uses}

There are agricultural uses for leek, such as pest control for organic vegetable production. Leek may have preventative efficacy against root-knot nematode damage. It has been shown that rotating Chinese leek with cucumber (Cucumis sativus L.) reduced the gall index by $70.2 \%$ and intercropping Chinese leek with tomato reduced the gall index by $41.1 \%$ (Huang et al. 2016). Additionally, leek extracts sprayed on sweet pepper plants (Capsicum annuum L.) were shown to repel aphids (Myzus persicae Sulzer). There is potential for aphid suppression by intercropping sweet pepper with leek (Amarawardana et al. 2007). There are many advantages of symbiosis with AM fungi, such as the fungi functioning as biofertilizer to make an agroecosystem more efficient (Berruti et al. 2016), and leek may enhance AM fungi symbiosis. Tomato (Solanum lycopersicum) intercropped with leek showed $20 \%$ greater colonization rates than monocropped tomato. Intercropping with leek allowed expression of bioprotective effects of AM fungi (Hage-Ahmed et al. 2013).

The overarching use of leek is culinary, to add flavor to dishes. It is important to wash leek thoroughly because the sheathing leaves may make it difficult to clean. Leek has a mild onion flavor and is used raw, cooked, or as a dried herb to enhance dishes. Leek is a nutritious vegetable, being low in calories and high in vitamin B6, vitamin C, folic acid, and iron (Danto 2013) (Table 1). Leek is also a good source of vitamin $\mathrm{K}$, which helps maintain healthy blood and bones, and vitamin $\mathrm{A}$, which helps maintain healthy eyesight and a healthy immune system (USDA FDC 2014). Cooking times vary with the stem thickness, but it is usually determined to be fully cooked once it can be easily pierced with a fork. Overcooking will create toughness, an undesirable outcome (Danto 2013). Leek produces an odor that can be absorbed by other foods, particularly fig and grape, so it helps to wrap leek in plastic before storing in a refrigerator (Danto 2013; Maynard and Hochmuth 2007). Additionally, leeks stored at lower than $35.6^{\circ} \mathrm{F}\left(2^{\circ} \mathrm{C}\right)$ are likely to develop a bitter flavor and mushy texture (Danto 2013). For commercial handling, it is recommended to use package icing, hydrocooling, or hydro-vacuum cooling followed by storage at $95 \%-100 \%$ relative humidity. Longterm storage (up to 2 months) can be achieved by holding in a refrigerated room and applying a controlled atmosphere consisting of $1 \%-2 \%$ oxygen and $2 \%-5 \%$ carbon dioxide concentrations (Maynard and Hochmuth 2007).
Medicinal uses have long been reported for leek. Hippocrates, the ancient Greek physician and "father of medicine," prescribed leek to cure nosebleeds (USDA SNAP 2015). Leek has antibacterial activities; a 2000 ppm concentration of aqueous leek extract has been shown to inhibit growth of Campylobacter bacterial species (C. jejuni, C. coli) (Lee et al. 2004). Leek has antifungal properties due to the presence of chitinases that hydrolyze chitin (Wong et al. 2010). Leek also has antioxidant properties. Leek contains 20.0-20.3 ppm polyphenols. Polyphenols are a beneficial group of functional molecules with antioxidant properties that contain one or more benzene rings and a varying number of hydroxyl, carbonyl, or carboxyl groups (Abuajah et al. 2015). Closely related Chinese leek was found to have a novel antioxidant peptide (CLP-2) that can protect cells against superoxide anions such as $\mathrm{O}_{2}^{-}$(Hong et al. 2014).

Leek has high amounts of organo-sulfur compounds, which are commonly found in the Allium genus. These compounds contain sulfur atoms bound to a cyanate group or carbon atom. The functional properties of these compounds are obtained after disrupting the cells and exposing them through chewing, cutting, or crushing. Leek is a rich source of inulin, a nonstarchy carbohydrate classified as a prebiotic (Muir et al. 2007; Abuajah et al. 2015). Additionally, there is a decreased risk of stomach and colon cancer that coincides with high consumption of Allium vegetables like leek (Tattelman 2005). In an in vitro study with Chinese leek, extracts were shown to inhibit melanoma cancer cell growth and induce apoptosis (Shao et al. 2004).

\section{References}

Abuajah, C. I., A. C. Ogbonna, and C. M. Osuji. 2015. "Functional components and medicinal properties of food: A review." Journal of Food Science Technology 52 (5): 2522-2529.

Alan, S., F. Duzgun, A. Kaska, F. Celebi-Toprak, and A. R. Alan. 2019. "Production of Chinese chive (Allium tuberosum) as potted herb." Acra Horticulturae 1251:135-138.

Amarawardana, L. P. Bandara, V. Kumar, J. Pettersson, V. Ninkovic, and R. Glinwood. 2007. "Olfactory response of Myzus persicae (Homoptera: Aphididae) to volatiles from leek and chive: potential for intercropping with sweet pepper." Acta Agriculturae Scandinavica Section B-Soil and Plant Science 57 (1): 87-91.

Armengol, J., A. Vicent, R. Sales, J. Garcia-Jimenez, and J. M. Rodríguez. 2001. "First report of basal rot of leek caused by Fusarium culmorum in Spain." The American Phytopathological Society 85 (6): 679. 
Baumann, D. T., M. J. Kropff, and L. Bastiaans. 2000. "Intercropping leeks to suppress weeds." Weed Research 40:359-374.

Berruti, A., E. Lumini, R. Balestrini, and V. Bianciotto. 2016. "Arbuscular mycorrhizal fungi as natural biofertilizers: Let's benefit from past successes.” Frontiers in Microbiology 6:1559.

Biesiada, A., E. Kolota, S. Pietr, M. Stankiewicz, and K. Matkowski. 2002. "Evaluation of some biological methods of pink root rot control on leek." In XXVI International Horticultural Congress: Managing Soil-Borne Pathogens: A Sound Rhizosphere to Improve Productivity 635:187-194.

Castner, J. L. 2004. "Amaryllidaceae - Amaryllis Family." In Photographic Atlas of Botany and Guide to Plant Identification, 214-215. Gainesville, Florida: Feline Press.

Daly, H. V., J. T. Doyden, and A. H. Purcell III. 1998. “Order Thysanoptera (Thrips)." In Introduction to Insect Biology and Diversity, 436-440. Oxford: Oxford University Press.

Danto, R. 2013. Using, storing, and preserving leeks. MSU Extension Bulletin HNI51. https://www.canr.msu.edu/ uploads/resources/pdfs/leeks_(hni51).pdf

Dittmar, P. J., E. J. McAvoy, R. N. Raid, P. Roberts, H. A. Smith, X. Martini, J. Desaeger, J. W. Noling, S. Zhang, and L. Zoterelli. 2019. Onion, Leek, and Chive Production in Florida. In Vegetable Production Handbook of Florida, 203-221. CV299. Gainesville: University of Florida Institute of Food and Agricultural Sciences. https://edis.ifas.ufl.edu/ cv299

Doherty, M. A., and T. F. Preece. 1978. "Bacillus cereus prevents germination of uredospores of Puccinia allii and the development of rust disease of leek, Allium porrum, in controlled environments." Physiological Plant Pathology $12: 123-132$.

FAOSTAT. 2019. "Crops." Food and Agriculture Organization (FAO) of the United Nations. http://www.fao.org/ faostat/en/?\#data/QC.

Hage-Ahmed, K., J. Krammer, and S. Steinkellner. 2013. "The intercropping partner affects arbuscular mycorrhizal fungi and Fusarium oxysporum f. sp. lycopersici interactions in tomato." Mycorrhiza 23:543-550.
Hong, J., T.-T. Chen, P. Hu, J. Yang, and S.-Y. Wang. 2014. "Purification and characterization of an antioxidant peptide (GSQ) from Chinese leek (Allium tuberosum Rottler) seeds." Journal of Functional Foods 10:144-153.

Huang, Y.-H., Z.-C. Mao, and B.-Y. Xie. 2016. "Chinese leek (Allium tuberosum Rottler ex Sprengel) reduced disease symptom caused by root-knot nematode." Journal of Intensive Agriculture 15 (2): 364-372.

Kiremit, M. S., and H. Arslan. 2016. "Effects of irrigation water salinity on drainage water salinity, evapotranspiration and other leek (Allium porrum L.) plant parameters." Scientia Horticulturae 201:211-217.

Kiremit, M. S., and H. Arslan. 2018. "Response of leek (Allium porrum L.) to different water levels under rain shelter." Communications in Soil Sciences and Plant Analysis 49 (1): 99-108.

Lee, C.-F., C.-K. Han, and J.-L. Tsau. 2004. "In vitro inhibitory activity of Chinese leek extract against Campylobacter species." International J. of Food Microbiology 94 (2): 169-174.

Liu, G. D., E. H. Simonne, K. T. Morgan, G. J. Hochmuth, S. Agehara, and R. Mylavarapu. 2019. Chapter 2. Fertilizer Management for Vegetable Production in Florida. In Vegetable Production Handbook of Florida. CV296. Gainesville: University of Florida Institute of Food and Agricultural Sciences. https://edis.ifas.ufl.edu/cv296

MacKenzie, J. 2018. Growing leeks in home gardens. University of Minnesota Extension. https://extension.umn.edu/ vegetables/growing-leeks

Martin-Guay, M. O., A. Paquette, J. Dupras, and D. Rivest. 2018. "The new green revolution: Sustainable intensification of agriculture by intercropping." Science of the Total Environment 615:767-772.

Maynard, D. M., and G. J. Hochmuth. 2007. Knott's Handbook for Vegetable Growers. Hoboken: John Wiley and Sons.

McDonald, M. B. 2000. "Seed priming." In Seed Technology and Its Biological Basis, edited by M. Black and J. D. Bewley, 287-316. Boca Raton: CRC Press.

Muir, J. G., S. J. Shepherd, O. Rosella, R. Rose, J. S. Barrett, and P. R. Gibson. 2007. "Fructan and free fructose content of common Australian vegetables and fruit." Journal of Agricultural Food Chemistry 55:6619-6627. 
Nasir, M. S. A., A. Nunez, L. C. McKeever, and O. M. Olanya. 2018. "Effects of arbuscular mycorrhizal fungal inoculations on the growth and polyphenol levels of garden leek (Allium porrum)." Journal of Plant Protection Research 58 (1): 83-90.

Shao, J., J. Dai, and J. K. H. Ma. 2001. "A pilot study on anticancer activities of Chinese leek." The Journal of Alternative and Complementary Medicine 7 (5): 517-522.

Stephens, J. 2018. Leek-Allium ampeloprasum L. (Porrum group). HS620. Gainesville: University of Florida Institute of Food and Agricultural Sciences. https://edis.ifas.ufl.edu/ mv087

Swamy, K. R. M., and R. V. Gowda. 2006. "Leek and shallot." In Handbook of Herbs and Spices, 365-389. Boca Raton: CRC Press LLC.

Tattelman, E. 2005. "Health effects of garlic." American Family Physician 72 (1): 103-106.

Theunissen, J., and G. Schelling. 1996. "Pest and disease management by intercropping: Suppression of thrips and rust in leek." International Journal of Pest Management 42 (4): 227-234.

Traunfeld, J., K. Phillips, and P. Yen. 2010. Leeks. GE 113. University of Maryland Extension and The Home and Garden Information Center. https://extension.umd.edu/ sites/extension.umd.edu/files/_docs/programs/hgic/ GIEI_veggie_pubs/GE113\%20Leeks.pdf

USDA Food Data Central (FDC). 2014. “Leek, raw." Food Data Central. https://fdc.nal.usda.gov/fdc-app.html\#/ food-details/787796/nutrients

USDA Supplemental Nutrition Assistance Program (SNAP). 2015. “Oregon leeks." Oregon State Extension Service. https://www.oregon.gov/ode/students-and-family/ childnutrition/F2S/Documents/LEEKS_1_product $\% 20$ poster_eng.pdf

Wong, J. H., T. B. Ng, R. C. Cheung, X. J. Ye, H. X. Wang, S. K. Lam, P. Lin, Y. S. Chan, E. F. Fang, P. H. Ngai, L. X. Xia, X. Y. Ye, Y. Jiang, and F. Liu. 2010. "Proteins with antifungal properties and other medicinal application from plants and mushrooms." Applied Microbiological Biotechnology 87:1221-1235.
Xie, Y., and H. L. Kristensen. 2017. "Intercropping leek (Allium porrum L.) with dyer's woad (Isatis tinctoria L.) increases rooted zone and agro-ecosystem retention of nitrogen." European J. of Agronomy 82:21-32.

Zuo, C., C. Li, Y. Wei, C. Hu, Q. Yang, J. Yang, O. Sheng, R. Kuang, G. Deng, M. K. Biswas, and G. Yi. 2015. “The toxic mechanism and bioactive components of Chinese leek root exudates acting against Fusarium oxysporum f. sp. cubense tropical race 4." European Journal of Plant Pathology 143:447-460. 
Table 1. Nutrition of common leek (Allium porrum L.). This table shows the composition of proximates in raw leek. (Source: USDA Food Data Central, 2014).

\begin{tabular}{|c|c|c|c|c|c|}
\hline Proximates & & $100 \mathrm{~g}$ & 1 cup $(89 \mathrm{~g})$ & 1 leek (89 g) & 1 slice $(6 \mathrm{~g})$ \\
\hline Water & $g$ & 83 & 73.87 & 73.87 & 4.98 \\
\hline Energy & kcal & 61 & 54 & 54 & 4 \\
\hline Protein & g & 1.5 & 1.33 & 1.33 & 0.09 \\
\hline Total lipid (fat) & $g$ & 0.3 & 0.27 & 0.27 & 0.02 \\
\hline Carbohydrate, by difference & $\mathrm{g}$ & 14.15 & 12.59 & 12.59 & 0.85 \\
\hline Fiber, total dietary & $g$ & 1.8 & 1.6 & 1.6 & 0.1 \\
\hline Sugars, total & $g$ & 3.9 & 3.47 & 3.47 & 0.23 \\
\hline \multicolumn{6}{|l|}{ Minerals } \\
\hline Calcium, Ca & $\mathrm{mg}$ & 59 & 53 & 53 & 4 \\
\hline Iron, Fe & $\mathrm{mg}$ & 2.1 & 1.87 & 1.87 & 0.13 \\
\hline Magnesium, Mg & $\mathrm{mg}$ & 28 & 25 & 25 & 2 \\
\hline Phosphorus, $\mathrm{P}$ & $\mathrm{mg}$ & 35 & 31 & 31 & 2 \\
\hline Potassium, $\mathrm{K}$ & $\mathrm{mg}$ & 180 & 160 & 160 & 11 \\
\hline Sodium, $\mathrm{Na}$ & $\mathrm{mg}$ & 20 & 18 & 18 & 1 \\
\hline Zinc, Zn & $\mathrm{mg}$ & 0.12 & 0.11 & 0.11 & 0.01 \\
\hline \multicolumn{6}{|l|}{ Vitamins } \\
\hline Vitamin C, total ascorbic acid & $\mathrm{mg}$ & 12 & 10.7 & 10.7 & 0.7 \\
\hline Thiamin & $\mathrm{mg}$ & 0.06 & 0.053 & 0.053 & 0.004 \\
\hline Riboflavin & $\mathrm{mg}$ & 0.03 & 0.027 & 0.027 & 0.002 \\
\hline Niacin & $\mathrm{mg}$ & 0.4 & 0.356 & 0.356 & 0.024 \\
\hline Vitamin B-6 & $\mathrm{mg}$ & 0.233 & 0.207 & 0.207 & 0.014 \\
\hline Folate, DFE & $\mu g$ & 64 & 57 & 57 & 4 \\
\hline Vitamin B-12 & $\mu \mathrm{g}$ & 0 & 0 & 0 & 0 \\
\hline Vitamin A, RAE & $\mu \mathrm{g}$ & 83 & 74 & 74 & 5 \\
\hline Vitamin A, IU & IU & 1667 & 1484 & 1484 & 100 \\
\hline Vitamin E (alpha-tocopherol) & $\mathrm{mg}$ & 0.92 & 0.82 & 0.82 & 0.06 \\
\hline Vitamin D (D2 + D3) & $\mu \mathrm{g}$ & 0 & 0 & 0 & 0 \\
\hline Vitamin D & IU & 0 & 0 & 0 & 0 \\
\hline Vitamin K (phylloquinone) & $\mu \mathrm{g}$ & 47 & 41.8 & 41.8 & 2.8 \\
\hline \multicolumn{6}{|l|}{ Lipids } \\
\hline Fatty acids, total saturated & $\mathrm{g}$ & 0.04 & 0.036 & 0.036 & 0.002 \\
\hline Fatty acids, total monounsaturated & $\mathrm{g}$ & 0.004 & 0.004 & 0.004 & 0 \\
\hline Fatty acids, total polyunsaturated & g & 0.166 & 0.148 & 0.148 & 0.01 \\
\hline Fatty acids, total trans & $\mathrm{g}$ & 0 & 0 & 0 & 0 \\
\hline Cholesterol & $\mathrm{mg}$ & 0 & 0 & 0 & 0 \\
\hline \multicolumn{6}{|l|}{ Other } \\
\hline Caffeine & $\mathrm{mg}$ & 0 & 0 & 0 & 0 \\
\hline
\end{tabular}

